Љиљана Ђурић*

Филолошки факултет

Универзитет у Београду
371.3::811.134.2'243

https://doi.org/10.18485/zivjez.2020.40.1.10 Оригинални научни рад

\author{
Александра Беговић \\ Филозофски факултет \\ Универзитет у Приштини \\ са седиштем у Косовској Митровици
}

\title{
СТРУЧНА СПРЕМА НАСТАВНИКА СТРАНИХ ЈЕЗИКА У ШКОЛСТВУ СРБИЈЕ: ПРАВИЛНИЦИ И ПРАКСА (2003 - 2020)
}

Предмет овог рада јесте анализа измена и допуна правилника о стручној спреми наставника страних језика у српском систему образовања, насталих током прве две деценије XXI века. Истраживање има за циљ утврђивање - из перспективе анализе јавних политика динамике, карактера и ефеката промена које се тичу нормативног дефинисања стручности наставника страних језика, а посебна пажња посвећује се улози различитих актера код доношења анализираних измена и допуна. Резултати истраживања показују да су после 2003. године, када је, на основу широког консензуса, уведена крупна новина у тој области, правилници незнатно мењани, али да су знатне измене настале напуштањем испитних процедура које су, ради обезбеђења и контроле квалитета кадра који улази у школство, првобитно (2003.) утврђене. Напуштањем наведених процедура отворена је могућност различитих интерпретација одредби правилника, па некада и постављања партикуларних интереса изнад општих.

Кључне речи: језичка образовна политика Србије, јавна политика, страни језици, стручна спрема наставника, актери, 2003 $-2020$.

* ljiljana.djuric.55@gmail.com 


\section{1. Уводне напомене}

Дефинисање степена и врсте стручне спреме који појединцима омогућују рад у школству од прворазредног је значаја за сваки систем образовања, те се тим задатком баве пре свега надлежна министарства, а затим и научнообразовне установе које образују поменути кадар, стручна удржења која окупљају наставнике одређеног предмета и други. Иницијативе за измене и допуне правила важећих у одређеном тренутку долазе посебно до изражаја у преломним реформским периодима, када од расположивости стручног кадра неретко зависи увођење новина у систем образовања.

Да би се сагледали њени релевантни аспекти - нпр. улога државе и других актера, њихово виђење потреба епохе у којој живимо које значајно (некада и пресудно) утиче на обликовање нормативних решења итд. - овако дефинисану проблематику нужно је посматрати из перспективе анализе јавних политика, која феномен поставља у историјско-политички контекст, али и критички анализира интервенције актера, њихове интересе, те ефекте и последице њиховог делања.

Поред теоријских и методолошких напомена, рад садржи приказ одлика правилника о стручној спреми наставника страних језика донесеног реформске 2003. године - када се тежило успостављању консензуса у вези са питањем увођења страног језика у први разред основне школе, као и свих утврђених процедура које су тај правилник допуњавале и које су представљале вид обезбеђења квалитета наставе страних језика, нарочито на раном узрасту; у раду се затим анализирају измене и допуне које су уследиле већ 2004. године; приказани су, такође, резултати анкете бивших студената Филолошког факултета Универзитета у Београду који су на основним студијама стекли потврду о поседовању компетенције нивоа Б2 према Заједничком европском оквиру за живе језике (у даљем тексту 3Е0); у закључним напоменама, поред осталог, из критичке перспективе указује се на нежељене ефекте и могуће последице анализираних промена и предлажу правци даљег развоја у тој области система образовања. 


\section{2. Теоријски оквир истраживања и методолошке напомене}

Као теоријски оквир истраживања изабрана је анализа јавних политика, и то у првом реду присуп који се бави генезом јавних политика, онај, наиме, који омогућује да се кроз приказ историјата промена јавних политка одговори на питање како оне настају и како се мењају. Будући да се истраживање односи на језичке образовне политике, теоријски оквир укључује и постулате макросоциолингвистике, критичке социолингвистике и глотодидактике. Језичку образовну политику, као део језичке политике сваке земље и истовремено један од њених најважнијих инструмената, посматрамо, дакле, као јавну политику, то јест првенствено као резултат деловања „државе у акцији“ (Милер 2006: 3) по моделу одозго-на-доле, али и као резултат деловања других актера јавне акције. Истичући утицај и тих актера, који нису доносиоци одлука, али могу значајно допринети обликовању, или преобликовању, нормативних решења, указујемо на значај политичких процеса по моделу одоздо-на-горе. ${ }^{1}$

1 О важности оба процеса у новије време постоји свест и у законодавној власти Републике Србије, која је Законом о министарствима (ступио на снагу 26. априла 2014. године) основала Републички секретаријат за јавне политике (РСЈП) као посебну организацију, са следећим задацима: „Овим законом предвиђено је да РСЈП обавља стручне послове који се односе на: анализу, идентификовање потреба и достављање иницијатива за израду стратешких докумената којима се утврђују јавне политике; обезбеђивање усклађености предлога стратешких докумената којима се утврђују јавне политике и нацрта закона са усвојеним стратешким документима којима се утврђују јавне политике, у поступку њиховог доношења; давање иницијатива за унапређење процедура за израду стратешких докумената којима се утврђују јавне политике; припремање предлога стратешких докумената којима се утврђуј јавне политике из делокруга свих органа државне управе, као и друге послове одређене законом.Тоукључује:давањепретходногмишљења опотребиспровођења анализе ефеката и о потпуности садржаја приложене анализе ефеката; помоћ предлагачима прописа при успостављању механизма за праћење и анализу ефеката прописа током њихове примене; прикупљање и обраду иницијатива привредних субјеката, других правних лица и грађана 
Околност да су оба аутора истраживања у извесним периодима била непосредни учесници, или пак сведоци, доношења измена и допуна правилника који су овде предмет интересовања, у рад уноси елементе аутоетнографског истраживања ${ }^{2}$. Поред студије случаја и упоредне анализе нормативних аката, коришћен је и метод интервјуисања и анкетирања: представника факултета који образују наставнике страних језика и њихових бивших студената, као и других релевантних учесника или сведока доношења анализираних измена и допуна. Такав приступ омогућио је примену тријангулације као битног поступка у отклањању ограничења нормативног приступа у анализи јавних политика (Милер 2006: 26; Ласкум 2014: 392). Омогућио је, такође, увиђање, тачније, потврђивање, извесних карактеристика новијих јавних (образовних) политика у Србији, које смо већ имали прилике да констатујемо у досадашњим истраживањима, као што је, на пример, одсуство културе њиховог праћења и евалуације (Ђурић 2016: 358, 359).

\section{3. Студија случаја: реформа образовања 2001-2004. године и решавање проблема мањка стручног кадра у настави страних језика}

Целовита реформа образовања под владом др Зорана Ђинђића, започета после демократских промена у Србији, ставила је учење страних језика на политичку агенду. Већ целу деценију уназад, од почетка деведесетих година XX

за измену неефикасних прописа на републичком нивоу; подношење иницијативе надлежним предлагачима прописа за измену неефикасних прописа; учешће у организовању обука државних службеника који раде на пословима који су повезани са анализом ефеката прописа; обављање послова везаних за праћење и анализу институционалних и кадровских капацитета за спровођење регулаторне реформе, као и друге послове одређене законом.“ (преузето са званичног сајта РСЈП, www.rsjp.gov.rs, приступљено 20. IX 2020.).

2 О особеностима аутоетнографских истраживања детаљније у Ђурић (2016: 321 и даље). 
века, у Србији је постојала изразита тензија у вези са тим питањем. Она се нарочито исказивала у настојању такорећи сваке основне школе да уведе енглески језик, док је надлежно министарство инсистирало на задржавању свих страних језика који су се тада учили у нашем основном школству (енглески, немачки, руски и француски, а од краја XX и почетка XXI века, и италијански и шпански). Министарство је свим школама које су располагале стручним наставницима - а то су, по тада важећем правилнику, били искључиво наставници ${ }^{3}$ и професори ${ }^{4}$ датог страног језика - одобравало увођење страног (најчешће енглеског) језика као изборног предмета од III разреда основне школе ${ }^{5}$, али немогућност проналажења стручних наставника, посебно у мањим срединама, често је представљала препреку за остварење те жеље коју су, без сумње, делили и ученици, и родитељи, и локална средина. Стога је иницијатива реформатора ${ }^{6}$ система образовања била да се један страни језик (углавном се мислило на енглески) уведе као основни предмет ${ }^{7}$ (то јест да се, као и школски предмети Српски / Матерњи језик и Математика, учи од почетка до краја школовања), а да се други страни језик, као обавезан предмет, уведе од V разреда основне школе. Како је

3 Носиоци диплома виших педагошких школа.

4 Носиоци диплома четворогодишњих академских студија.

5 Страни језик као обавезан предмет учио се од $V$ разреда основне школе, a страни језика као изборни предмет (који је постајао обавезан за ученике који су се за њега определили) почев од III разреда. На крају основне школе, фонд часова из обавезног и изборног страног језика био је, такорећи, изједначен, што је ученицима који су настављали школовање у средњим школама са само једним страним језиком омогућавало да бирају онај који желе да наставе.

6 Реч је у првом реду о министру просвете проф. др Гаши Кнежевићу, помоћницима министра доц. др Тинде Ковач Церовић, мр Желимиру Попову, проф. др Србијанки Турајлић, проф. др Рефику Шећибовићу, али и о свим другим учесницима у реформским процесима, међу којима су и ауторке овог истраживања.

7 Статус страног језика у првом циклусу промењен је Правилником из 2012. од основног у обавезни предмет у првом циклусу образовања и васпитања. 
мањак стручног кадра, посебно за наставу енглеског језика, био могућа препрека остваривању овог реформског решења које је имало широку, мада не и потпуну, подршку јавности ${ }^{8}$, било је неопходно омогућити онима који су имали висок ниво компетенције из страног језика да се укључе у наставу, и то као стручан кадар.

Та је намера изискивала доношење потпуно нових решења у подзаконском акту, те се послу приступило већ у другој половини 2002. године. На конференцији Реформа образовања у Републици Србији - први кораци и предстојећи изазови, одржаној у Београду од 5. до 7. септембра 2002. године, јавности је саопштено драматично стање када је у питању квалификациона структура наставника страних језика: проценат наставника без прописане стручне спреме који су у школској 1999/2000. години изводили наставу страних језика био је нешто преко 21\% на нивоу Србије без Косова, а у неким је окрузима, нпр. Браничевском, Јужнобанатском и Средњобанатском, достизао близу 40\%. Међу наставницима без прописане стручне спреме, наставу страног језика држали су: наставници неког другог страног језика, апсолвенти и студенти филолошких група, професори различитих школских предмета (историје, хемије, информатике), учитељи, васпитачи, али и туризмолози, лица са вишом техничком или вишом економском школом, свршени гимназијалци, лица са средњом стручном школом - техничком, саобраћајном, туристичком итд ${ }^{9}$.

Такво стање захтевало је хитно изналажење решења, утолико пре што су у области наставе страних језика стратешка опредељења Министарства била амбициозна:

- постепено увођење два обавезна страна језика у основно образовање;

- померање почетка учења страног језика на што млађи узраст, по могућству почев од првог разреда;

8 О контроверзама поводом раног учења страног језика више у Ђурић (2016: 354-373).

9 Из материјала са Конференције, на основу Јановски (2000). 
- ширење разноврсних системских решења и модела програма, као што су, рецимо, интензивно учење страног језика и двојезична настава. ${ }^{10}$

\section{1. Консултативни процес и доношење одлука}

У периоду који је претходио консултативном процесу, било је покушаја да се изнађу задовољавајућа решења за отклањање проблема недостатка стручног кадра, нарочито за енглески језик. Тако је, рецимо, Одсек за англистику Филозофског факултета Универзитета у Новом Саду сачинио Предлог програма за двогодишњу наставу за преквалификацију наставника који већ поседују универзитетску диплому из неке од филолошких струка, како би се оспособили за наставу енглеског језика у основним школама. Предлог програма за преквалификацију упућен Министарсву предвиђао је осам предмета, један четворосеместрални (Интензивни курс из савременог енглеског језика, са шест часова недељно), пет двосеместралних и два једносеместрална. За реализацију тог програма, Одсек је тражио нова радна места за два наставника, три асистента, три лектора и једног техничког секретара. Тражена је и савремено опремљена језичка лабораторија, виртуелна учионица, видеобим са лаптопом, четири компјутера са штампачима и једним скенером, два касетофона, књиге, речници, уџбеници, приручници и друго.

Свакако, са становишта једног факултетског одсека, наведени предлог програма могао је деловати као изводљив. Са становишта доносиоца одлука, у нашем случају Министарства, поменуто решење, уколико би било прихваћено, требало је множити са пет, колико је, у том периоду, било англистичких одсека или катедара на српским универзитетима ${ }^{11}$, а вероватно

10 Из материјала са Конференције.

11 Филолошки факултет Универзитета у Београду, Филозофски факултет Универзитета у Новом Саду, Филозофски факултет Универзитета у Нишу, Филозофски факултета Универзитета у Приштини са седиштем у Косовској Митровици, Филолошко-уметнички факултет Универзитета у Крагујевцу. 
и још неколико пута, будући да је постојао мањак стручних наставника и за друге стране језике. Осим што је предвиђао знатна кадровска и материјална средства, наведени предлог програма у двогодишњем трајању могао је дати прве кадрове тек за три године (година дана за спровођење припрема, конкурса, уписа итд, две године за завршавање програма), што је био сувише дуг период с обзиром на то да је реформа требало да се примењује од школске 2003/2004. године.

Исти недостатак може се приписати још једном предлогу који се често јављао, ато је увођењестепенованихстудија, које би омогућиле да се са дипломом првог степена (двогодишње или трогодишње студије) ради у прва два циклуса основног образовања. ${ }^{12}$

Други аргумент против описаних опција просветне власти нашле су у анализи решења којима су прибегле друге државе са недовољно стучног кадра за увођење страног (енглеског) језика. Један од примера који је био прихватљив и за Србију нађен је у Швајцарској где су учитељи могли да држе наставу страног језика на раном узрасту уколико имају положен ниво Б2 из датог језика. Такав приступ, који с једне стране обезбеђује довољну компетенцију, а с друге реалистичан је и релативно брзо достижан, српски реформатори изабрали су са намером да га представе онима који су у систему образовања задужени за обезбеђивање поменутог кадра, а то су представници факултета који образују професоре страних језика, особито представници катедара и одсека за англистику.

Састанак министра просвете, његових помоћника и саветника са представницима факултета организован је 24 . марта 2003. године. Позивом који је потписао министар лично и који је упућен свим факултетима који су тада образовали професоре страних језика (наведени у напомени број 11), позвани су декани, продекани за наставу, руководиоци катедара за англистику и професори методике наставе енглеског језика. У позиву је назначено да ће састанак

12 Тадашња реформа предвиђала је деветогодишње обавезно образовање са три циклуса од по три године сваки. 
„бити посвећен изналажењу најбољег решења за промену Правилника о стручној спреми наставника, у делу који се односи на наставнике страних језика." На састанку, којем су присуствовали представници свих пет позваних факултета ${ }^{13}$, једногласно је закључено да је стање тешко и да се нешто хитно мора предузети. Разматране су различите опције, утврђено је да ниво компетенције мора бити барем Б2, као и да могућност полагања треба да имају наставници затечени у школама, дипломци било ког наставничког факултета, апсолвенти англистике и учитељи. Договорено је, такође, да ће се оформити комисија која ће даље разрадити структуру испита (заједничку за све језике), критеријуме вредновања (заједничке за све језике), програмске садржаје (по језицима) и друго. Јасно је да су представници Министарства сматрали да спровођење испита треба на себе да преузму факултети, али представници факултета то нису разумели на исти начин.

После наведеног, одржано је још неколико састанака на којима су се искристалисала озбиљна размимоилажења у ставовима присутних ${ }^{14}$, до мере да су саветници предложили министру да се тестирање кандидата повери акредитованим институцијама уместо факултетима. Ипак, из Министарства је уследило неколико дописа којима су факултети позвани да се изјасне да ли желе да учествују у изради теста и у спровођењу испита. Пошто је потврдан одговор послао само Филозофски факултет Универзитета у Нишу, сви остали факултети су о томе обавештени, те је Министарство предложило да Филозофски факултет Универзитета у Нишу преузме све послове у вези са провером језичке компетенције на нивоу Б2, тражећи од осталих да доставе мишљење о предлогу (и сматрајући да су сагласни уколико то не учине до датог рока).

13 А из Министарства министар Гашо Кнежевић, помоћници министра Тинде Ковач Церовић и Србијанка Турајлић, као и саветници министра Савица Тома, Анка Ивковић, Александра Беговић и Љиљана Ђурић.

14 Подсећамо да је атентат на премијера Зорана Ђинићићаизвшен 12. марта 2003. године и да неки аналитичари (нпр. Бошко Јакшић, Политика, 2. октобар 2020.) сматрају да су тог дана „реформе дефинитивно страдале“. 
Од тог периода, дакле, сви даљи послови договарани су и разрађивани са Филозофским факултетом Универзитета у Нишу, са Одсеком за англистику, а стални саговорници представницима Министарства биле су проф. др Слободанка Китић, тада продекан за наставу, и др Тања Пауновић, заменик руководиоца Одсека за англистику.

\section{2. Брига о квалитету будућег наставног кадра}

Актери који су наставили рад на осмишљавању и организацији испита чинили су то са пуном свешћу о одговорности за квалитет наставе коју ће у будућности изводити кандидати са положеним испитом Б2 при факултету. Стога су решења за која су се определили захтевала улагање великих напора, како од стране организатора тако и од стране кандидата. Брига о квалитету била је видљива у сваком сегменту концепције и организације испита:

- структура испита: испит се састојао из писменог и усменог дела; писмени део садржао је: Слушање и разумевање, Читање и разумевање, Граматика и употреба енглеског језика и Писање; усмени део предвићао је Разговор;

- сваки део испита и сваки елемент писменог дела био је елиминаторан, а праг пролазности за сваки део испита и сваки елемент писменог дела био је 75\%;

- да би приступио усменом делу, кандидат је морао положити сваки од делова писменог;

- критеријуми за оцењивање Писања (састав на задату тему) односили су се на процену садржине, форме и структуре рада, на опсег употребљених граматичких конструкција и вокабулара; критеријуми за оцењивање Разговора односили су се на граматику (опсег граматичких структура, граматичка тачност итд.) и дискурс, на богатство речника, на изговор и на способност интеракције;

- било је предвиђено да се испит, уколико се организује на више од једног факултета, одржава истог дана и буде исти за све факултете; 
- пријему докумената кандидата и испиту обавезно је присуствовао школски надзорник за енглески језик;

- организацију методичког оспособљавања кандидата који би положили испит преузимало је на себе Министарство просвете.

\section{3. Доношење новог правилника}

Правилник о измени и допуни Правилника о врсти стручне спреме наставника и стручних сарадника у основној школи (Службени гласник РС - Просветни гласник 4/2003) донет је 23. августа 2003. године. Члан 2, став 2. односи се на предмет нашег истраживања и гласи:

Наставу и друге облике образовно-васпитног рада у предметној настави из страног језика као основног предмета у првом циклусу основног образовања и васпитања могу да изводе лица, и то:

1) професор одговарајућег страног језика;

2) професор разредне наставе;

3) дипломирани филолог са савладаним програмом увођења у посао наставника и положеним испитом за лиценцу;

4) дипломирани школски педагог или школски психолог;

5) дипломирани педагог или дипломирани психолог;

6) наставник одговарајућег страног језика, у складу са чл. 145. и 146. Закона о основној школи;

7) наставник одговарајућег страног језика са положеним стручним испитом по прописима из области образовања или лиценцом за наставнике;

8) наставник разредне наставе;

9) лице које испуњава услове за наставника предметне наставе у основној школи, а које је на основним студијама положило испите из педагошке психологије или педагогије и психологије, као и методике наставе.

Лица из става 2. тач. 2), 3), 4), 5), 8) и 9) овог члана треба да поседују знање језика најмање на нивоу Б2 (Заједничког европског оквира). Ниво знања Б2 доказује се уверењем о 
положеном одговарајућем испиту на некој од филолошких катедри универзитета у Србији, или међународно признатом исправом за ниво знања језика који је виши од Б2 (Ц1 или Ц2 Заједничког европског оквира), а чију ваљаност утврђује Министарство просвете и спорта или организација коју овласти Министарство просвете и спорта.

Лица из става 2. овог члана треба да савладају и обуку за нову концепцију образовања у трајању од 80 сати у организацији Министарства просвете и спорта, односно друге организације коју овласти Министарство просвете и спорта.

Лица из става 2. овог члана треба да савладају и обуку за наставу страног језика на раном узрасту у трајању од 25 сати у организацији Министарства просвете и спорта, односно друге организације коју овласти Министарство просвете и спорта.

Предност за извођење наставе из страног језика као основног предмета у првом циклусу основног образовања и васпитања из става 2. овог члана имају професор, односно наставник одговарајућег страног језика, професор разредне наставе, наставник разредне наставе и професор педагогије са претходно завршеном педагошком академијом или учитељском школом.

Из наведеног текста измене и допуне правилника јасно је да се значајно одступило од првобитног договора постигнутог на састанку од 24. марта 2003. године:

- Измена и допуна омогућује рад искључиво у првом циклусу основног образовања и васпитања, а не у првом и другом.

- Затечени наставници и апсолвенти нису обухваћени изменом и допуном јер те категорије нису биле предвиђене ширим законским оквиром.

- Додате су нове категорије, на пример педагози и психолози.

- Отворена је могућност рада са међународно признатим сертификатима на нивоу Ц1 и Ц2 (сачињен је њихов списак на основу којег је Министарство утврђивало ваљаност сертификата).

- Спецификована је обавеза завршавања методичке обуке.

- Прецизиране су категорије које имају предност при запошљавању. 


\section{4. Резултати прва два испитна рока}

Први испитни рокза полагање испита из енглеског језика на нивоу Б2 ЗЕО одржан је септембра 2003. године на Филозофском факултету Универзитета у Нишу. Од 369 кандидата који су полагали испит, испит је у целости положило 87, и то:

- 3 наставника разредне наставе;

- 8 професора разредне наставе;

- 69 филолога;

- 3 наставника других школских предмета;

- 4 педагога/ психолога.

Већ следећег испитног рока, организованог јануара 2004. године, поред Филозофског факултета Универзитета у Нишу, укључили су се Филозофски факултет Универзитета у Новом Саду и Филолошки факултет Универзитета у Београду.

Збирни резултати за оба испитна рока били су следећи: од 665 кандидата који су полагали испит, положило је 181 кандидат, и то:

- 8 наставника разредне наставе;

- 22 професора разредне наставе;

- 141 филолог;

- 6 наставника других школских предмета;

- 4 педагога/ психолога.

Сама чињеница да је мање од једне трећине кандидата успела да положи испит, доказује оправданост ригорозних критеријума који су тада примењени. Школски надзорници анкетирани 2012. године за потребе другог истраживања истакли су да по њиховом сазнању није било притужби на рад наставника који су положили испит Б2 из енглеског језика на неком од поменутих факултета (Ђурић 2016: 358, 359).

\section{5. Крај реформе и промена партнерских институција министарства}

Од марта 2004. године нови министар просвете, проф. др Љиљана Чолић (у влади др Војислава Коштунице), зауставља 
реформу и укида страни језик у првом разреду основне школе. Убрзо (у септембру исте године) замењује је др Слободан Вуксановић који враћа страни језик у први разред; проблем недостатка наставника страних (енглеског) језика нови министар решава задржавајући правилник, али мењајући партнерске институције у послу провере компетенције и методичке обуке: уместо са факултетима, успоставља сарадњу са Задужбином Илије М. Коларца (Ђурић 2016: 379, 340).

\section{4. Нормативна анализа: измене и допуне правилника}

Допуне и измене правилника који регулишу врсту стручне спреме наставника страних језика нису се много мењале до данас након објављивања Правилника из 2003. године којим је врло јасно и прецизно регулисано ко може да изводи наставу страног језика у првом циклусу образовања и васпитања и под којим условима. Ти услови су обухватали квалитативни и квантитативни аспект. Квантитативни се огледа у списку звања предавача, који је много дужи у односу на раније, док је у квалитативном смислу прецизиран ниво знања који је неопходан да би неко могао да реализује наставу страног језика, као и примарна вокација, којом се гарантује методичко и педагошко образовање реализатора наставе страног језика. Дакле, тиме је с једне стране у великој мери обезбеђено квалитетно и стручно спровођење наставе страног језика, а са друге стране олакшано је остваривање постављених циљева образовања, којима се страни језик сврстао у обавезне предмете од првог разреда основне школе.

Следеће озбиљније промене у виду измена и допуна правилника о врсти стручне спреме наставника и стручних сарадника објављене су у Просветном гласнику 7/2012 од 7. новембра 2012. године. Оне су резултат измена у високошколском образовању насталим прилагођавањем Болоњском процесу и изменама у номенклатури звања. Те измене су морале директно да се уграде и у Закон о основама образовања и васпитања из 2009. године, у поглавље које 
регулише образовање наставника, васпитача и стручних сарадника:

У установи образовно-васпитни рад обављају: наставник, васпитач и стручни сарадник. Наставник, васпитач и стручни сарадник јесте лице које је стекло одговарајуће високо образовање:

1) на студијама другог степена (мастер академске студије, специјалистичке академске студије или специјалистичке струковне студије) по пропису који уређује високо образовање, почев од 10. септембра 2005. године;

2) на основним студијама у трајању од најмање четири године, по пропису који је уређивао високо образовање до 10. септембра 2005. године [...]

Лице из ст. 2 и 3 овог члана мора да има образовање из психолошких, педагошких и методичких дисциплина стечено на високошколској установи у току студија или након дипломирања, од најмање 30 бодова и шест бодова праксе у установи, у складу са Европским системом преноса бодова.

Програм за стицање образовања из става 4. овог члана реализујевисокошколскаустановау оквируакредитованог студијског програма или као програм образовања током читавог живота, у складу са прописима којима се уређује високо образовање.

Ова законска одредба условила је нове измене и допуне које су објављене у горепоменутом Просветном гласнику 7/2012. У односу на претходни текст Правилника из 2003. године у члану 2, проширена је листа звања са 9 на 19. На иницијативу декана Филолошког факултета Универзитета у Београду, постојећој листи додато је и звање дипломираног библиотекара-информатичара, а затим је готово свако од звања проширено мастер звањем, на пример:

Професор одговарајућег страног језика - мастер професор језика и књижевности или дипломирани библиотекаринформатичар, односно мастер библиотекар-информатичар. 
У овом Правилнику постоје и друге измене које су резултат реорганизације одређених високообразовних институција које су увиделе неопходност за променама у свом раду ради прилагођавања потребама рада у школи. Тако је, рецимо, Учитељски факултет у Београду увео специјални модул за енглески језик који је конципиран тако да омогући додатну наставу енглеског језика која студентима нуди могућност да знање језика оствари на нивоу Ц1 ЗЕО и то докажу полагањем одређеног испита. Након успешно положеног испита, студенти добијају специјално уверење о положеном испиту. Пошто је Учитељски факултет желео да овај пројекат валоризује и учини га препознатљивим у законској номенклатури, поднео је захтев ресорном Министарству за признавање тог модула као регуларног звања и додатне могућности свршеним студентима да прошире своју делатност на реализацију наставе енглеског језика у првом циклусу образовања и васпитања. По добијању позитивног стручног мишљења од Завода за унапређивање образовања и васпитања, Министарство је акредитовало модул и уврстило звање у Правилник из 2012. у којем је ова новина верификована на следећи начин:

Члан 2

Наставу и друге облике образовно-васпитног рада у предметној настави из страног језика као обавезног предмета у првом циклусу основног образовања и васпитања могу да изводе лица, и то:

11) Професор разредне наставе који је на основним студијама савладао програм Модула за енглески језик (60 ЕСБ - Европски систем преноса бодова) и који поседује уверење којим доказује савладаност програма модула и положен испит који одговара нивоу Ц1 ЗЕО.

Поред овог звања, у истом Правилнику је на листу лица која могу да изводе наставу страног језика у првом циклусу образовања и васпитања, под бојем 10, уврштен и Професор разредне наставе и енглеског језика за основну школу. Ово се звање, заправо, стиче на Педагошком факултету у 
Бијељини, Република Српска. С обзиром на то да су дипломе са високошколских установа Републике Српске еквивалентне дипломама у Србији, где су и признате, ово звање морао је да уврсти и наш законодавац. Питање еквиваленције решено је чланом 143. Закона о основама система образовања и васпитања у поглављу које регулише утврђивање стеченог образовања наставника, васпитача и стручних сарадника, где стоји:

Када је образовање стечено у некој од република СФРЈ до 27. априла 1992. године, у Црној Гори до 16. јуна 2006. године или у Републици Српској, а врста образовања не одговара врсти образовања која је прописана чланом 140. овог закона, министар, по претходно прибављеном мишљењу одговарајуће високошколске установе, решењем утврђује да ли је врста образовања одговарајућа за обављање послова наставника, васпитача, односно стручног сарадника [...]

Ово звање се, међутим, већ у Правилнику из 2016. године више не појављује, а и укидају се звања са шестим степеном образовања (наставник страног језика или наставник разредне наставе) која су се налазила у претходним правилницима на листи звања под редним бројевима од 6 до 8. У правилницима о стручној спреми наставника и стручних сарадника у основној школи, који су касније објављени (Просветни гласник бр. 15/2013, 2/2016, 10/2016, 11/2016 і 2/2017, 13/2018) није било значајнијих промена у делу текста који се односи на реализаторе наставе страних језика у првом циклусу образовања. Иста констатација односи се и на правилник донет децембра 2020. године, којим су нешто прецизније дефинисане основне студије. 


\section{5. Факултети: могућност полагања испита Б2 током основних студија}

Имајући у виду промене политичких околности и везивање Министарства за друге партнере $\mathrm{e}^{15}$, неке катедре и одсеци за англистику у новоакредитоване програме уносе могућност полагања енглеског језика као изборног/ помоћног предмета на нивоу Б2 (или вишем) 3ЕО:

- Филолошки факултет Универзитета у Београду уводи два нивоа за енглески језик као изборни/ помоћни предмет: A2 и Б2, а ниво је назначен у индексу и у додатку дипломи.

- На Филозофском факултету Универзитета у Новом Саду сви студенти који полажу страни језик као изборни имају у званичном препису оцена, као и у додатку дипломи, наведено да су положили дати предмет, у чијем називу стоји ниво по 3ЕО, нпр. Енглески језик Б2.2, или Француски језик А2.1 и слично.

- На Филолошко-уметничком факултету Универзитета у Крагујевцу, различите катедре нуде страни језик као изборни предмет на прве две (катедре за енглески и за немачки језик) или три године (катедре за руски, француски, шпански и италијански језик). Када је у питању енглески језик као изборни, у спецификацији предмета назначено је да на крају прве године студенти достижу ниво између Б1 и Б2, на крају друге године ниво Б2, а на крају треће године - ниво Ц1 ЗЕО.

- На Филозофском факултету Универзитета у Нишу није прецизиран ниво који се постиже на крају курса из страног језика као изборног/ помоћног предмета.

- На Филозофском факултету Универзитета у Приштини са седиштемуКосовској Митровици студенти накатедрамазаенглески језик и књижевност, као и за руски језик и књижевност бирају други страни језик као изборни који се слуша прве две године студирања, а и студенти осталих филолошких група имају могућност да бирају изборни предмет Страни језик који слушају два семестра. У понуди су енглески, руски, француски, немачки и италијански језик.

15 И нешто касније, 2014. године, ту склоност наставља министар др Срђан Вербић, који потписује уговор о сарадњи са Британским саветом. 


\section{1. Резултати анкете: измене у начину полагања испита из енглеског језика на нивоу Б2 - пример Филолошког факултета Универзитета у Београду}

Свршени студенти ${ }^{16}$ Филолошког факултета Универзитета у Београду које смо анкетирали похађали су вежбе из енглеског језика као изборног / помоћног предмета на нивоу Б2 ЗЕО 2010, 2011, 2012, 2017. и 2018. године. У наставку дајемо резиме резултата обраде анкета.

- Сви анкетирани:

- имајуубележен ниво Б2 уиндексу иудодатку дипломи;

- потврђују да се испит састојао из писменог и усменог дела,

- $\quad$ и да је писмени део садржао Граматику и употребу енглеског језика.

- Ниједан анкетирани:

- није добио сертификат о наведеном нивоу компетенције као посебан документ (како је било предвиђено Правилником из 2003. године);

- није радио у гимназији као наставник енглеског језика.

- Већина анкетираних тврди:

- да им на часовима није речено да са положеним испитом на нивоу Б2 могу радити у првом циклусу основне школе као стручан кадар за енглески језик $(71,4 \%)$;

- да настава није била прилагођена потребама за рад у основној школи $(85,7 \%) ;$

- да су на писменом делу полагали Читање и разумевање писаног текста (71,4\%);

- да су на писменом делу полагали Писање (57\%, од којих један анкетирани прецизира да је у питању био диктат);

16 Користимо прилику да изразимо захвалност учесницима у анкети, који су нам својим ажурним и прецизним одговорима омогућили стицање увида у карактеристике анализираног испита. 
- да се усмени део испита састојао из „разговора о изабраној теми“; „познавања текстова који су обрађивани на часу“; „конверзације”; „разговора на тему слике / питања које смо извукли на картици“; „морфосинтаксичке анализе“; „описа понуђене сличице“; „описивања и одговорање на питања у вези са извученом сликом“; „текста од 4 до 5 редова“; „комуникације, усмене провере граматике уз теоријска објашњења“; „кратке конверзације на задату тему или опис слике“ и слично;

- $\quad$ да се не сећа услова пролазности (57\%), сем да је услов за полагање усменог био положен писмени део и да је за пролаз био потребан одређени број поена (неки тврде 51\% од укупног броја поена) на писменом који је представљао једну целину;

- да се не сећа критеријума на основу којих је оцењивана писана и усмена продукција; они који се сећају, за писану продукцију наводе „правописну тачност“, „број тачних одговора“, а за усмену продукцију, „квалитет одговора, елоквенцију, начин одговарања“, „адекватан, што детаљнији опис слике“;

- $\quad$ да су се после положеног испита осећали довољно компетентни за раду прва четири разреда основне школе $(71,4 \%)$;

- да нису радили нити на једном нивоу формалног образовања $(85,7 \%)$;

- да су радили у неформалном образовању (курсеви језика) као наставници енглеског језика (57\%).

- Половина анкетираних тврди да:

- није имала Слушање и разумевање говора као елемент писменог дела испита.

- Када су у питању други послодавци (ван формалног и неформалног образовања), на питање Да ли је неки други послодавац узео у обзир као релевантан ниво Б2 који сте положили? најтипичнији одговори су следећи: „Не“; „Не, сви 
траже да енглески буде први језик“; „Предавање енглеског језика преко интернета“; „Био сам запослен у фирми [...] где сам навео да говорим енглески језик, што је било неопходно да бих се запослио“; „Нисам прецизирала да сам положила ниво Б2 на факултету, већ сам само навела да имам знање енглеског језика на траженом нивоу“; „Не. Они послодавци који су тражили диплому, тражили су међународно признате сертификате“; „Не, нажалост. На многим актуелним радним местима (контакт центри, приватне школе језика, рад на преводима за агенције) није била битна диплома ни првог страног језика, а камоли другог. Траже препоруке за Вас као радника од других и добијете тест, као и усмену проверу језика (разговор) да провере како владате језиком, али нико не тражи било какву диплому. Претпостављам да је разлог тај да би што мање платили ангажман, као услов на скоро свим радним местима (не рачунајући државне школе до којих се тешко долази) траже диплому средње школе“.

Из свега наведеног видљиве су велике разлике у односу на испит Б2 који је 2003. установљен са Филозофским факултетом Универзитета у Нишу, а који су касније прихватили и остали факултети.

\section{6. Закључна разматрања}

Начин на који је 2003. године започето решавање проблема недостатка стручног кадра за стране језике, нарочито енглески, специфичан је по изузетном напору доносилаца одлука, у првом реду министра и његових помоћника, да истрају у проналажењу консензуса и у подели одговорности са научно-образовним установама које школују наставнике тог предмета. Иако је било кризних тренутака, када је деловало да се неће успети и када су се јављали предлози са новим решењима, консензус и учешће факултета ипак су остварени. То је омогућило да већ од фебруара 2004. године близу 200 формално стручних и језички истински компетентних наставника преузме наставу страног (енглеског) језика на раном узрасту. Још важнија је, међутим, 
чињеница да је захваљујући тој упорности изабраном решењу обезбеђено трајање до данашњих дана, што је показала и анализа касније донесених измена и допуна правилника.

Измене и допуне које су уследиле нису унеле суштински преокрет у поимању стручности наставника страних језика. Оне су углавном представљале неминовна усаглашавања са новим законима (увођење звања мастера, признавање диплома стечених у Републици Српској итд), а само су две измене усвојене на иницијативу актера као што су Учитељски факултет Универзитета у Београду (уношење звања Професор разредне наставе који је на основним студијама савладао програм Модула за енглески језик) и Филолошки факултет Универзитета у Београду (звање Дипломирани библиотекаринформатичар или Мастер библиотекар-информатичар), уз напомену да је иницијатива Учитељског факултета темељно и транспарентно припремана и спровођена почев од акредитације модула, док се за иницијативу уношења у правилник звања Библиотекар-информатичар не може са сигурношћу утврдити да ли је била лична иницијатива декана Филолошког факултета или иницијатива на основу одлуке Наставно-научног већа ${ }^{17}$.

И на крају овог дела закључних разматрања, истакнимо да нормативна анализа правилника о стручној спреми наставника страних језика указује на истовремено присуство две супротне тежње законодавца: све веће специјализације у основној струци (факултетска диплома, мастер) с једне стране, али и отварање ка другим струкама (филолози различитих језика, наставници других предмета, психолози, педагози, библиотекари) с друге.

Оно што је без сумње велика промена није видљиво у тексту измена и допуна правилника. Реч је о интегрисању полагања испита из енглеског језика на нивоу Б2 3ЕО у

17 У вези са тим, разговарали смо са професорима методике наставе страних језика који се предају у нашим школама; они се не сећају да је то питање било када стављено на дневни ред Наставно-научног већа Филолошког факултета. 
основне студије, што је случај на Филолошком факултету Универзитета у Београду, али и на већини осталих факултета који образују наставнике страних језика, мада је свака установа то учинила на другачији начин. Анкета на коју су се одазвали бивши студенти Филолошког факултета показује извесну неуједначеност по генерацијама, па чак и у оквиру исте генерације, а неки описи испита, посебно усменог дела, не одговарају ни стандардним захтевима просечног нивоа Б2, а камоли нивоу „јаког“ Б2, усаглашеног са потребама наставе на раном узрасту, какав је био предвиђен 2003. године. Иза истих формулација, дакле, крије се сасвим различита реалност, што делом објашњава извесну равнодушност послодаваца према тако стеченој и представљеној компетенцији.

Са становишта теорије анализе јавних политика, студија случаја показала је како може изгледати генеза одређене јавне политике када се државни актер определи за поштовање свих почетних фаза које се у секвенцијалној анализи сматрају битним: идентификација проблема на основу констатованог стања; стављање решавања проблема на политичку агенду као део ширег стратешког оквира; разматрање опција, опредељивање за решење око којег је постигнут широк консензус; развој програма и његова имплементација. Остале фазе, као што су праћење имплементације програма и вредновање његових учинака (in itinere, после одређеног периода итд), уз евентуално предузимање мера за побољшање програма или за његову реоријентацију, у анализираном случају нисмо могли да сагледамо. Као што је већ напоменуто, реформа је прекинута 2004. године, а министри који су даље преузимали дужност определили су се за друге партнерске институције.

Данас у Србији не можемо доћи до података о броју наставника који страни језик предају на основу поседовања компетенције на нивоу Б2 или Ц1 ЗЕО, нити о томе да ли остварују наставу искључиво у првом циклусу основног образовања и васпитања, како је правилником и предвиђено, или предају и у другом циклусу, а можда и у средњој школи. 
Утврђивање таквих података, као и лонгитудинална истраживања ефеката наставе коју држе ти наставници, нису могући без дозволе и координације надлежног министарства, што треба да имају у виду истраживачи који намеравају да се баве тим питањем.

Ако се окренемо будућности, а имајући у виду de facto измене настале у анализираној области, аутори овога рада подржавају предлоге изнесене у документу Друштва за стране језике и књижевности Србије, Стратегија развоја језичког образовања - страни, регионални, класични, наследни и знаковни језик у систему образовања Србије ${ }^{18}$, у којем се у оквиру области приоритета Јачање система за осигурање квалитета у језичком образовању поред осталог предлаже:

Доношење измена и допуна Правилника о степену и врсти образовања наставника и стручних сарадника у основној школи којима би се укинула могућност ангажовања кандидата са нивоом Б2.

Такав став заснован је на чињеници да је напуштањем партнерства са факултетима надлежно министарство изгубило могућност контроле уједначености садржаја испита и критеријума оцењивања, те се данас не може са сигурношћу тврдити да је компетенција стечена студирањем страног језика као изборног / помоћног предмета на филолошким студијама довољна за рад у првом циклусу основног образовања и васпитања.

Истакнимо на крају да би овај рад могао представљати допринос увођењу праксе праћења и вредновања јавних образовних политика (у области страних језика), које представљају веома значајне фазе њиховог спровођења, а које су и даље мањкаве у нашем друштву.

18 Документ је објављен на сајту Друштва за стране језике и књижевности Србије. Сајт је посећен септембра 2020. године. 


\section{ЛИТЕРАТУРА}

\section{Корпус: закон и подзаконска акта}

Закон о основама система образовања и васпитања, Службени гласник РС, бр. 72/2009.

Правилник о измени и допуни Правилника о врсти стручне спреме наставника и стручних сарадника у основној школи, Службени гласник РС - Просветни гласник, бр. 4/2003.

Правилник о степену и врсти образовања наставника и стручних сарадника у основној школи, Службени гласник РС - Просветни гласник, бр. 11/2012.

Правилник о степену и врсти образовања наставника и стручних сарадника у основној школи, Службени гласник РС, бр. 11/2012, 15/2013, 2/2016, 10/2016, 11/2016, 2/2017, 3/2017, 13/2018, $11 / 2019,2 / 2020,8 / 2020,19 / 2020$.

\section{Референце}

Ђурић 2016: Љ. Ђурић, Страни језици у образовној политици Србије. Београд: Филолошки факултет Универзитета у Београду.

Јановски 2000: K. Janovski, Nastava stranih jezika u osnovnim školama na početku reforme i novog milenijuma. Primenjena lingvistika, 1, 1-30.

Ласкум 2014: P. Lascoumes, Normes. In : Boussaguet et al. (ed.), Dictionnaire des politiques publiques (4 $4^{\mathrm{èm}}$ édition, $1^{\mathrm{èr}}$ édition 2004) (pp. 391-397). Paris : Presses de Sciences Po.

Милер 2006: P. Muller, Les politiques publiques, (6 $6^{\text {ème }}$ édition mise à jour, $1^{\text {ère }}$ édition 1990). Paris : Presses universitaires de France. 


\section{Ljiljana Đurić \\ Aleksandra Begović}

\section{LES QUALIFICATIONS PROFESSIONNELLES DES ENSEIGNANTS DE LANGUES VIVANTES EN SERBIE : DÉCRETS D'APPLICATION ET PRATIQUE (2003 - 2020)}

\section{Résumé}

L'objet de cet article est l'analyse des décrets portant modification du Décret d'application relatif aux qualifications professionnelles des enseignants de langues vivantes dans le système scolaire serbe, pris au cours des deux premières décennies du XXİ̀me siècle. Le but de la recherche présentée était de déterminer - du point de vue de l'analyse des politiques publiques - la dynamique, le caractère et les effets de ces modifications, mais également le rôle de différents acteurs non étatiques dans la formulation du texte des décrets.

L'approche choisie rend compte de la genèse et du changement d'une politique éducative : le point de départ est le bouleversement dans le domaine étudié qui a eu lieu en 2003, quand la possiblité a été donnée à des enseignants titulaires de qualifications en diverses matières scolaires d'enseigner une langue vivante (l'anglais avant tout) dans les trois premières années de l'école primaire, à condition de posséder un certificat de compétence de niveau B2 délivré par une faculté serbe formant des enseignants de langues, ou de niveau C1 ou C2 délivré par un organisme accrédité. Ce dispositif devait permettre la réalisation d'une réforme éducative qui introduisait l'apprentissage d'une première langue vivante obligatoire en première année de l'école primaire et une deuxième langue vivante à partir de la cinquième année.

La triangulation méthodologique utilisée dans la recherche (étude de cas, analyse normative et enquête), visant à palier les limites de l'analyse normative, a permis de montrer que les modifications de ce premier texte n'apportaient pas de changements importants. C'est plutôt l'abandon d'un certain nombre de procédures qui garantissaient le contrôle de la qualité des compétences des enseignants qui a mené à des interprétations diverses de certains articles des décrets, jusqu'à privilégier parfois des intérêts particuliers.

Mots clés: la politique linguistique éducative de la Serbie, les politiques publiques les langues vivantes, les qualifications professionnelles des enseignants de langues vivantes, les acteurs, 2003 à 2020. 